\title{
30. BIOSTRATIGRAPHIC AND PALEOCEANOGRAPHIC SYNTHESIS OF ODP LEG 141, OFF SOUTHERN CHILE ${ }^{1}$
}

\author{
Dorothee Spiegler, ${ }^{2}$ Carla Müller, ${ }^{3}$ Sigurd Locker, ${ }^{2}$ and Joachim Schönfeld ${ }^{2}$
}

\begin{abstract}
Bioevents of calcareous and siliceous nannofossils and microfossils were used to establish biostratigraphic zonations for Pliocene to Quaternary sections recovered at Sites 859 through 863 off southern Chile during Ocean Drilling Program Leg 141. Stable oxygen isotope data from Site 861 were employed to subdivide the upper Quaternary sequence, which is the first attempt at directly correlating oxygen isotope events from the southeastern Pacific with the SPECMAP stack. Paleomagnetic data could not be used for age calibration because paleomagnetic signals are strongly overprinted. Paleoceanographic interpretations are based on microfossil records as well as on stable oxygen isotopes measured from foraminifers at Site 861.
\end{abstract}

\section{INTRODUCTION}

During Ocean Drilling Program (ODP) Leg 141, Quaternary to Pliocene sedimentary sequences were encountered in 13 holes drilled at five sites between $45^{\circ}$ and $47^{\circ} \mathrm{S}$, off the coast of southern Chile (Fig. 1). In this region the active oceanic spreading center of the Chile Ridge is subducted under the continental plate of South America. The main objectives of ODP Leg 141 were to investigate the geologic and tectonic processes associated with the subduction of oceanic crust and sediment material under the continental crust of the South American Plate. The sedimentary sequences recovered consist of predominantly clayey to silty sediments that vary in consolidation because of tectonic processes at the accretionary wedge. The sediments yielded rare to common calcareous and siliceous nanno- and microfossils including coccolithophorids, planktonic and benthic foraminifers, silicoflagellates, ebridians, actiniscidians, diatoms, and radiolarians, which were used for stratigraphic and paleoceanographic interpretations. Additionally, stable oxygen and carbon isotopes were analyzed from benthic and planktonic foraminifers found in Quaternary sediments at Site 861 .

\section{BIOSTRATIGRAPHY}

Biostratigraphy of Pliocene to Quaternary sediments is strongly influenced by paleoceanography. The zonations used for ODP Leg 141 are high latitude subdivisions that can be recognized in both hemispheres, and which differ distinctly from zonations described for mid and low latitudes.

The age determinations primarily conducted on calcareous nannoplankton and planktonic foraminifers are supported by results from silicoflagellate, ebridian, and benthic foraminifer studies. Both diatoms and radiolarians are present within the upper portions of the drilled sequences, but downhole they are absent or too rare to be useful for stratigraphic subdivisions. The zonations of the microfossil groups used and their correlations are summarized in Figure 2.

Generally, the biostratigraphic resolution is rather low owing to the scarcity of microfossils and the low diversity of assemblages that embrace mainly long ranging species of minor stratigraphic value. Low abundancy and diversity may be related to oceanographical and

\footnotetext{
${ }^{1}$ Lewis, S.D., Behrmann, J.H., Musgrave, R.J., and Cande, S.C. (Eds.), 1995, Proc, $O D P_{2}$ Sci. Results, 141: College Station, TX (Ocean Drilling Program).

${ }^{2}$ Research Center for Marine Geosciences, Wischhofstrasse 1-3, Building 4, D-24148 Kiel, Federal Republic of Germany.

${ }^{3}$ Institute of Geology and Paleontology of the Johann-Wolfgang-Goethe University, Senckenberg-Anlage 32-43, D-60325 Frankfurt/Main. Federal Republic of Germany.
}

sedimentological factors (i.e., low surface-water paleotemperatures, dissolution of skeletons during and after deposition, and dilution of particles by high amounts of advected sediment). Dissolution of calcareous and siliceous nanno- and microfossils is probably affected to some extent by fluid circulation and compression within the accretionary wedge. Stress related to shearing within the wedge is evidenced by deformed foraminifers (Spiegler and Müller, this volume).

The biostratigraphy of calcareous nannoplankton from Sites 859 to 863 is summarized in Spiegler and Müller (this volume). Age determinations are based on the standard nannoplankton zonation of Martini (1971), which, however, is difficult to apply in higher latitudes due to low diversity assemblages. Nevertheless, the Pleistocene off southern Chile can be subdivided with some restrictions into Zones NN19 to NN21.

The first appearance (FA) of Emiliania huxleyi, which indicates the base of Zone NN21, usually falls within oxygen isotope Stage 8 at $0.27 \mathrm{Ma}$ (Thierstein et al., 1977). However, at Site 861 the first occurrence (FO) of Emiliania huxleyi was determined in Section 141-861C-4H-CC at $31.5 \mathrm{mbsf}$ within the younger Stage 6. This discrepancy might be due to the scarcity of Emiliania huxleyi below isotope Event 5. The nannoplankton Zone NN20/19 boundary, defined by the last appearance (LA) of Pseudoemiliania lacunosa, may be recognized in higher latitudes. It marks the lower/upper Pleistocene boundary at $0.47 \mathrm{Ma}$.

In this study, the Pliocene/Pleistocene boundary is determined by the FA of Gephyrocapsa oceanica at 1.6 Ma (Raffi and Rio, 1979), which corresponds to an elevated top of Zone NN18 compared with Berggren et al. (1985). The FA of $G$. oceanica coincides roughly with the last occurrence (LO) of Cyclococcolithus macintyrei and the extinction of discoasters, which conventionally define the Pliocene/ Pleistocene boundary. However, Cyclococcolithus macintyrei is too rare within the study area to be useful for biostratigraphic distinctions, and discoasters are missing in these latitudes.

The upper Pliocene cannot be subdivided using calcareous nannoplankton, since index fossils are missing. The oldest sediments recovered are late Pliocene in age, based on the presence of Pseudoemiliania lacunosa and small specimens of Gephyrocapsa sp. Such sediments are not older than 3.2 to $3.4 \mathrm{Ma}$. Unfortunately, age interpretations cannot be calibrated to the geomagnetic polarity pattern, because strong overprinting by high temperature fluids precludes collection of relevant data (Musgrave et al., this volume).

Biostratigraphic results using planktonic foraminifers from Sites 859 to 863 are combined with the calcareous nannoplankton stratigraphy by Spiegler and Müller (this volume). The assemblages of planktonic foraminifers observed in the study area are intermediate to those described from low latitudes (Blow, 1969; Bolli and Saunders, 


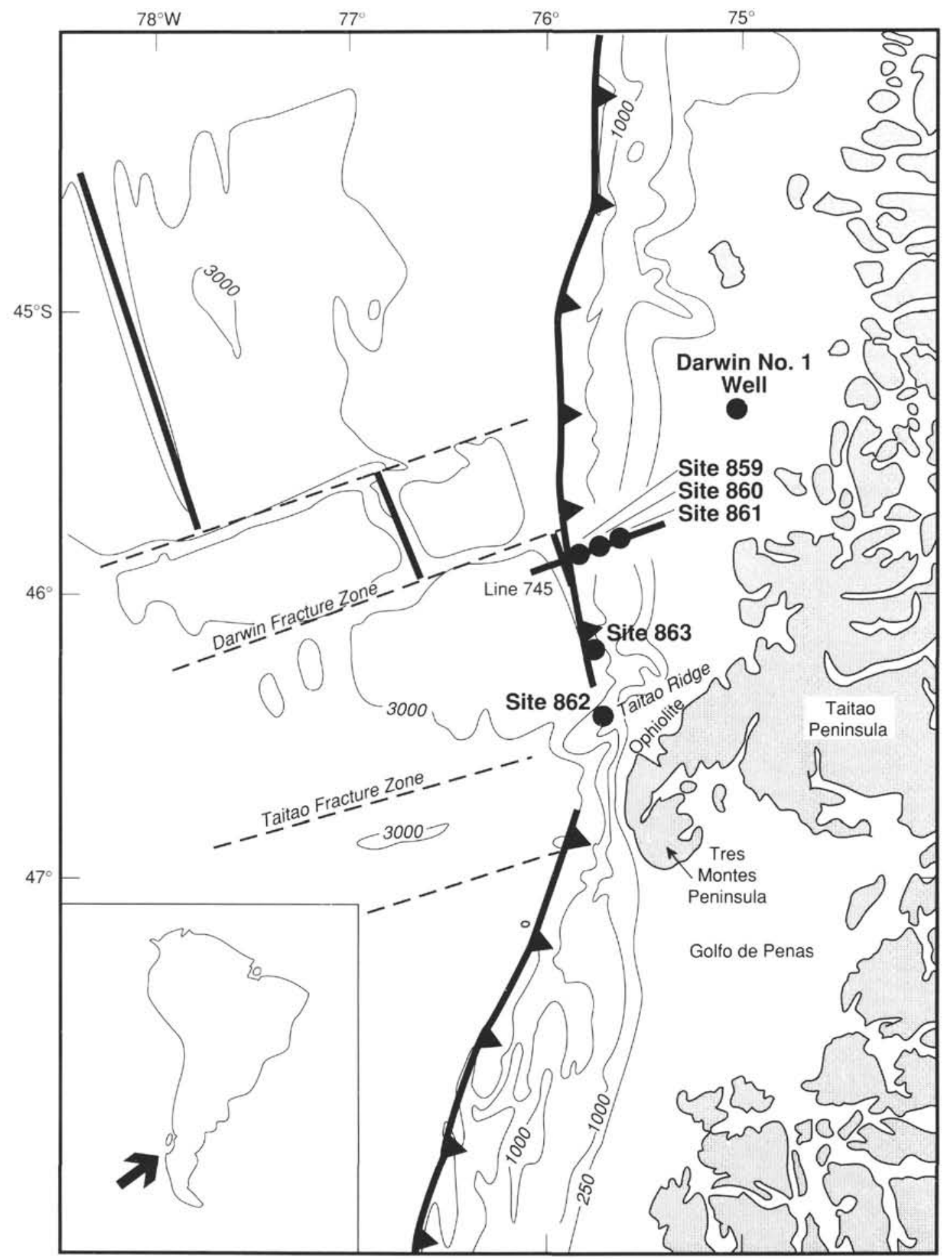

Figure 1. Location map of Leg 141 sites. Bathymetry in meters.

1985; Kennett and Srinivasan, 1983) and those from mid to high latitudes (Srinivasan and Kennett, 1981). According to present-day planktonic foraminifers, the investigated area falls into the southern Transition Zone, which is influenced by the Subtropical Zone and the Subantarctic Zone (Bé and Tolderlund, 1971).

The sediments recovered can be attributed to the Truncorotalia truncatulinoides Zone, the Globoconella inflata Zone, and the Globorotalia crassaformis Zone. Since the FO of T. truncatulinoides is strongly influenced by paleotemperatures, the base of this zone ap- pears diachronous (Jenkins and Gamson, 1993). The FA of $G$. inflata conventionally marks the early/late Pliocene boundary. Generally, abundance and diversity of the planktonic foraminifer assemblages found in Pliocene to lower Pleistocene sediments are low.

Beneath the cover of upper Pliocene to Pleistocene sediments at Site 862 off Taitao Ridge a sequence of rhyolitic and phyric basalts occurs. Intercalated in the basaltic sequence, a marine sandstone was found. The fine-grained portion of this sandstone yielded a number of late Paleocene planktonic and benthic foraminifers (Forsythe et al., 


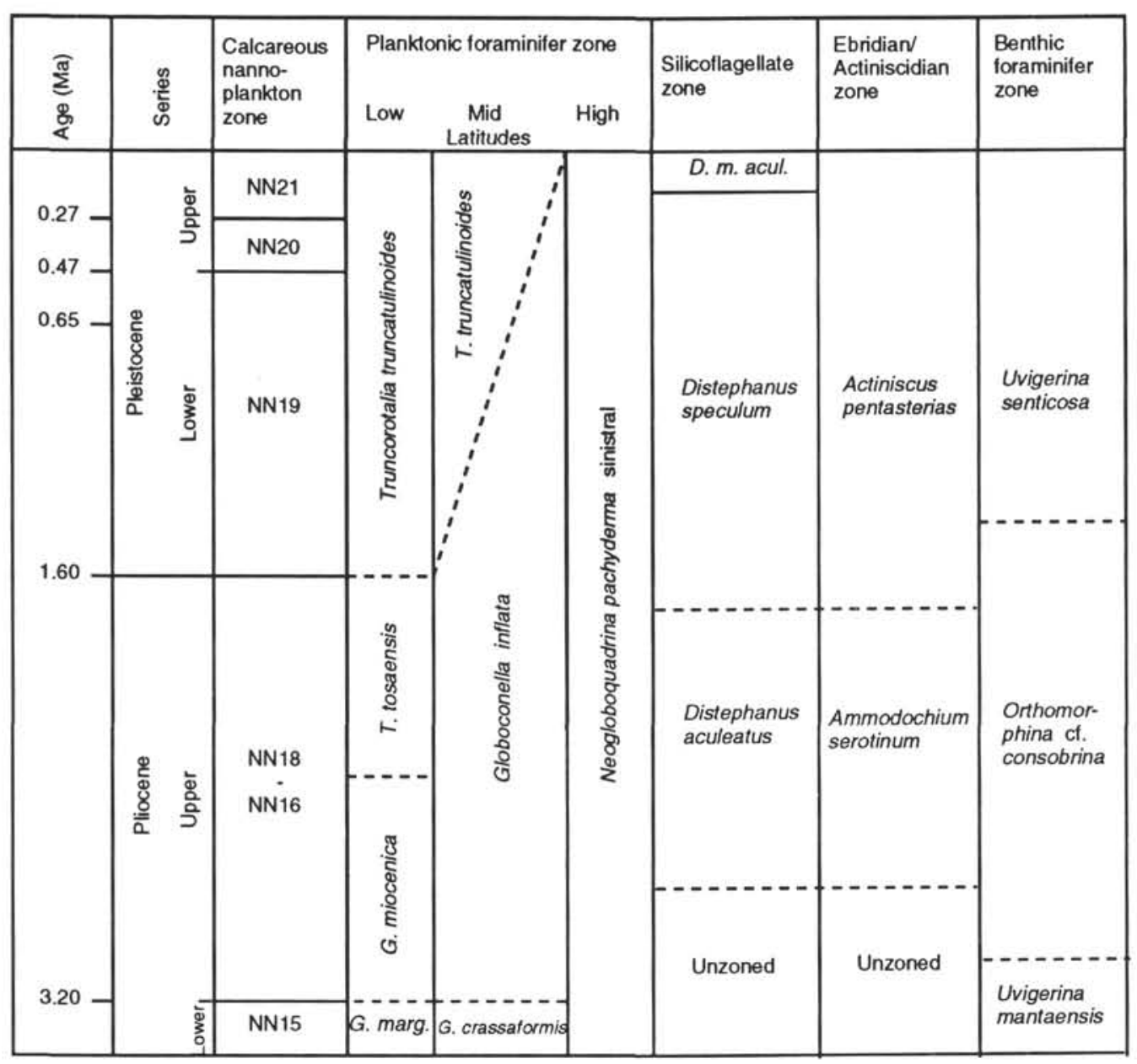

Figure 2, Biozonations applied for Leg 141, D. m. acul. = Dictyocha messanensis aculeata, G. = Globorotalia .

this volume). The late Paleocene age of the sediment contrasts with the Pliocene age of overlying volcanics and sediments.

The biostratigraphy of benthic foraminifers from Site 861 is documented by Schönfeld and Spiegler (this volume). Benthic foraminifers off the coast of Chile were first described by Orbigny (1839) and Brady (1884), and more recently by Boltovskoy and Theyer (1970) and Boltovskoy (1976), while Resig (1990) studied benthic foraminifers from the low latitudes off the coast of Peru. Although benthic foraminifers are predominantly ecological indicators, a zonation comprising three assemblage zones could be established for the region off the Chile coast (Fig. 2).

Oxygen and carbon stable isotopes from planktonic and benthic foraminifers are discussed by Schönfeld et al. (this volume). The oxygen isotope curve obtained from Quaternary sediments at Site 861 is correlated with the SPECMAP stack. The data indicate that the sequence down to $73 \mathrm{mbsf}$ extends to oxygen isotope Event 10.2, which is dated at $0.34 \mathrm{Ma}$.

The biostratigraphies of silicoflagellates and ebridians/actiniscidians are described in Locker (this volume). The assemblages recovered at Sites 860 and 861 are characteristic of the high latitudes of both hemispheres. Although species abundances and diversities are low, two biozonations could be distinguished comprising three and two zones, respectively. The LA events of the silicoflagellate Distephanus aculeatus and of the ebridian Ammodochium serotinum are good indicators for the Pliocene/Pleistocene boundary in high latitudes. At the sites studied both events approximate the elevated top of Zone NN18 at 1.6 Ma, as adopted in Spiegler and Müller (this volume).
No detailed diatom and radiolarian biostratigraphies were elaborated for this volume, but initial data may be found in Behrmann et al. (1992). According to Boden (this volume), diatoms cannot be used to provide biostratigraphic resolution, as they are too rare or the assemblages are dominated by long ranging species. Ecological preferences of diatom species indicate that upwelling did not exist off southern Chile during Neogene time.

Bioevents and related ages are listed in Tables 1 to 3 . The most complete biostratigraphic results were obtained from Site 861. The results from Sites $859,860,862$, and 863 are less complete. Figure 3 summarizes the biostratigraphic events and age assignments recognized for the investigated area.

\section{PALEOCEANOGRAPHY}

Documenting Pliocene to Pleistocene climate changes off southern Chile will increase our understanding of the climate history of South America. The present climate of southern Chile is strongly influenced by surface-water masses of the southern Pacific, especially those belonging to the subpolar and transitional water belts. The main influence, however, comes from the subpolar water masses of the Antarctic Circumpolar Current, which approaches the South American continent and divides at $39^{\circ}-40^{\circ} \mathrm{S}$. One branch of the current flows to the south where it joins the Cape Horn Current, the other turns to the north where it forms the Peru Current. The Peru Current transports cold nutrient-rich water northward to $15^{\circ} \mathrm{S}$. The current is bounded on the northwest by the Subtropical Convergence, separat- 
Table 1. Biostratigraphic events obtained from Site 859 .

\begin{tabular}{|c|c|c|c|c|}
\hline $\begin{array}{l}\text { Core, section, } \\
\text { interval }(\mathrm{cm})\end{array}$ & $\begin{array}{l}\text { Depth } \\
\text { (mbsf) }\end{array}$ & $\begin{array}{l}\text { Age } \\
\text { (Ma) }\end{array}$ & Event & Series \\
\hline $\begin{array}{c}141-859 \mathrm{~A}- \\
2 \mathrm{H}-\mathrm{CC} \\
4 \mathrm{H}-\mathrm{CC}\end{array}$ & $\begin{array}{l}10.74 \\
25.00\end{array}$ & $\begin{array}{l}<0.27 \\
>0.47\end{array}$ & $\begin{array}{l}\text { FO Emiliania huxlevi (N). Truncorotalia trumeatulinoides (PF) } \\
\text { LO Pseudoemiliana lacumosa (N) }\end{array}$ & Pleistocene \\
\hline $\begin{array}{c}141-859 \mathrm{~B}- \\
29 \mathrm{R}-\mathrm{CC} \\
37 \mathrm{R}-\mathrm{CC}\end{array}$ & $\begin{array}{l}389.20 \\
466.40\end{array}$ & $\begin{array}{l}<3.20 \\
<3.20\end{array}$ & $\begin{array}{l}\text { FO Globoconella inflata (PF) } \\
\text { FO Psesdomiliania lacumosa (N). Gephyrocapsa sp.. small (N) }\end{array}$ & upper Pliocene \\
\hline
\end{tabular}

Note: $\mathrm{FO}=$ first occurrence, $\mathrm{LO}=$ last occurrence, $\mathrm{N}=$ calcareous nannoplankton, $\mathrm{PF}=$ planktonic foraminifer.

Table 2. Biostratigraphic events obtained from Site $\mathbf{8 6 0}$.

\begin{tabular}{|c|c|c|c|c|}
\hline $\begin{array}{l}\text { Core, section. } \\
\text { interval }(\mathrm{cm})\end{array}$ & $\begin{array}{l}\text { Depth } \\
\text { (mbsf) }\end{array}$ & $\begin{array}{l}\text { Age } \\
(\mathrm{Mia})\end{array}$ & Event & Series \\
\hline $\begin{array}{r}141-860 \mathrm{~B}- \\
2 \mathrm{H}-2,60\end{array}$ & 3.50 & $<0.27$ & FO Emiliania huxleyi (N) & upper Pleistocene \\
\hline $\begin{array}{l}10 \mathrm{H}-\mathrm{CC} \\
16 \mathrm{X}-3.32\end{array}$ & $\begin{array}{r}78.10 \\
120.12\end{array}$ & $<1.60$ & $\begin{array}{l}\text { LO Helicospaera selitii }(\mathrm{N}) \\
\text { FO Gephyrocapsa oceanica }(\mathrm{N}) \text {, Truncorotalia trancatudinoides (PF) }\end{array}$ & lower Pleistocene \\
\hline $\begin{array}{l}17 R-3,128 \\
19 X-3,100 \\
21 R-1,72 \\
22 X-2.103 \\
62 X-3,114\end{array}$ & $\begin{array}{l}130.78 \\
141.10 \\
156.22 \\
167.63 \\
535.04\end{array}$ & $\begin{array}{l}>1.60 \\
>1.60 \\
>1.60 \\
>1.70 \\
<3.20\end{array}$ & $\begin{array}{l}\text { FO Cyclococcolithus macintrei }(\mathrm{N}) \\
\text { LO Ammodochitum sp. (E) } \\
\text { LO Distephamus aculeatus (S) } \\
\text { LO Ammodochitum serotinum (E) } \\
\text { FO Globoconella inflata (PF) }\end{array}$ & upper Pleistocene \\
\hline
\end{tabular}

Note: $\mathrm{FO}=$ first occurrence, $\mathrm{LO}=$ last occurrence, $\mathrm{N}=$ calcareous nannoplankton. $\mathrm{PF}=$ planktonic foraminifer. $\mathrm{S}=$ silicoflagellate, $\mathrm{E}=$ ebridian.

Table 3. Stratigraphic events obtained from Site 861.

\begin{tabular}{|c|c|c|c|c|}
\hline $\begin{array}{l}\text { Core, section. } \\
\text { interval }(\mathrm{cm})\end{array}$ & $\begin{array}{l}\text { Depth } \\
\text { (mbsf) }\end{array}$ & $\begin{array}{l}\text { Age } \\
(\mathrm{Mal})\end{array}$ & Event & Series \\
\hline $861 \mathrm{~B}-1 \mathrm{H}-1.75$ & 0.75 & 0.0098 & Oxygen isotope Event I.I & \multirow[t]{17}{*}{ upper Pleistocene } \\
\hline $86 \mathrm{IC}-1 \mathrm{H}-2.87$ & 2.37 & 0.0124 & Beginning of Termination lb & \\
\hline $861 \mathrm{~B}-1 \mathrm{H}-4.41$ & 4.91 & 0.0183 & Beginning of Termination la & \\
\hline $861 \mathrm{~B}-1 \mathrm{H}-5,115$ & 7.15 & 0.0235 & Oxygen isotope Event 2.2 & \\
\hline $861 \mathrm{IC}-2 \mathrm{H}-5,80$ & 9.80 & $<0.027$ & FCO Dictyocha messanensis aculeata (S) & \\
\hline $861 \mathrm{~A}-1 \mathrm{H}-4,109$ & 11.19 & 0.053 & Oxygen isotope Event 3.3 & \\
\hline $861 \mathrm{C}-2 \mathrm{H}-\mathrm{CC}$ & 12.50 & 0.065 & Oxygen isotope Event 4.2 & \\
\hline $86 \mathrm{IC}-3 \mathrm{H}-2.70$ & 14.70 & 0.080 & Oxygen isotope Event 5.1 & \\
\hline $861 \mathrm{C}-3 \mathrm{H}-5.60$ & 19.10 & 0.122 & Oxygen isotope Event 5.5 & \\
\hline $861 \mathrm{C}-4 \mathrm{H}-4.109$ & 27.59 & 0.135 & Oxygen isotope Event 6.2 & \\
\hline $861 \mathrm{C}-4 \mathrm{H}-\mathrm{CC}$ & 31.50 & $<0.270$ & FO Ëmiliania hux/evi (N) & \\
\hline $861 \mathrm{C}-5 \mathrm{H}-4.70$ & 35.50 & 0.171 & Oxygen isotope Event 6.5 & \\
\hline $861 \mathrm{IC}-5 \mathrm{H}-\mathrm{CC}$ & 41.00 & 0.194 & Oxygen isotope Event 7.1 & \\
\hline $861 \mathrm{C}-6 \mathrm{H}-3,56$ & 44.56 & 0.249 & Oxygen isotope Event 8.2 & \\
\hline $861 \mathrm{C}-7 \mathrm{H}-3,39$ & 52.80 & 0.310 & Oxygen isotope Event 9.1 & \\
\hline $861 \mathrm{C}-8 \mathrm{H}-\mathrm{CC}$ & 69.50 & 0.331 & Oxygen isotope Event 9.3 & \\
\hline $861 \mathrm{C}-10 \mathrm{H}-2,73$ & 73.23 & 0.341 & Oxygen isotope Event 10.2 & \\
\hline $861 \mathrm{C}-15 \mathrm{H}-\mathrm{CC}$ & 128.90 & 0.47 & LO Pseudoemiliania lacunosa (N) & \multirow[t]{4}{*}{ lower Pleistocene } \\
\hline $861 \mathrm{C}-16 \mathrm{X}-4,30$ & 133.70 & $<1.60$ & FO Truncorotalia trancatulioides (PF) & \\
\hline $861 C-19 X-1.60$ & 158.90 & 1.30 & LO Orthomorphia ef. consehrina (BF) & \\
\hline $861 \mathrm{C}-20 \mathrm{X}-\mathrm{CC}$ & 170.20 & 1.60 & FO Gephrocapsa oceanica (N) & \\
\hline $861 C-21 X-1.100$ & 171.20 & $>1.60$ & LO Distephanus aculeatus (S) LO Ammodoc himm sp. (E) & \multirow[t]{3}{*}{ upper Pliocene } \\
\hline $861 C-22 X-4.87$ & 185.30 & $>1.60$ & LO Ammodochium serotimum (E) & \\
\hline $861 \mathrm{D}-8 \mathrm{R}-1,46$ & 410.26 & $<3.20$ & FO Globoconella inflata (PF) & \\
\hline
\end{tabular}

Note: $F C O=$ first consistent occurrence, $F O=$ first occurrence, $L O=$ last occurrence. $N=$ calcareous nannoplankton. $P F=$ planktonic foraminifer. $\mathrm{BF}=$ benthic foraminifer, $\mathrm{S}=$ silicoflagellate. $\mathrm{E}=$ ebridian.

ing the subpolar waters of the Antarctic Circumpolar Current from the temperate waters of the South Pacific Gyre. The position of the Subtropical Convergence shows strong seasonal north-south fluctuations.

An increased abundance of calcareous nannofossils within the early Zone NN16 might indicate warm surface-water conditions preceding the late Pliocene cooling. However, calcareous and siliceous nanno- and microfossils demonstrate that cooler conditions prevailed during most of the late Pliocene. The assemblages are generally characterized by low species abundance and minor diversity, and by the presence of the cold-adapted silicoflagellate Distephanus speculum. Repeated occurrences of the warm-adapted silicoflagellate Dictyocha messanensis messanensis hint at oscillations of the transitional water belt during late Pliocene and early Pleistocene times. The occurrences may reflect mixing of transitional and subpolar water masses or the replacement of subpolar waters (Locker, this volume).

Variations of stable oxygen isotope values indicate paleotemperature fluctuations during the late Pleistocene. The warm intervals of the isotopic record are generally characterized by higher abundance of planktonic foraminifers. Although recent warm-water planktonic foraminifers are not found in the surface waters off the southern Chile coast, several subtropical species were recovered in uppermost Pleistocene sediments, including Globorotaloides hexagonus, Neogloboquadrina dutertrei, Beella digitata, Globigerina apertura, and Orbulina universa (Spiegler and Müller, this volume). The warm-water fluctuations of latest Pleistocene time are confirmed by enhanced occurrences of the warm-adapted silicoflagellate $D$. messanensis aculeata 


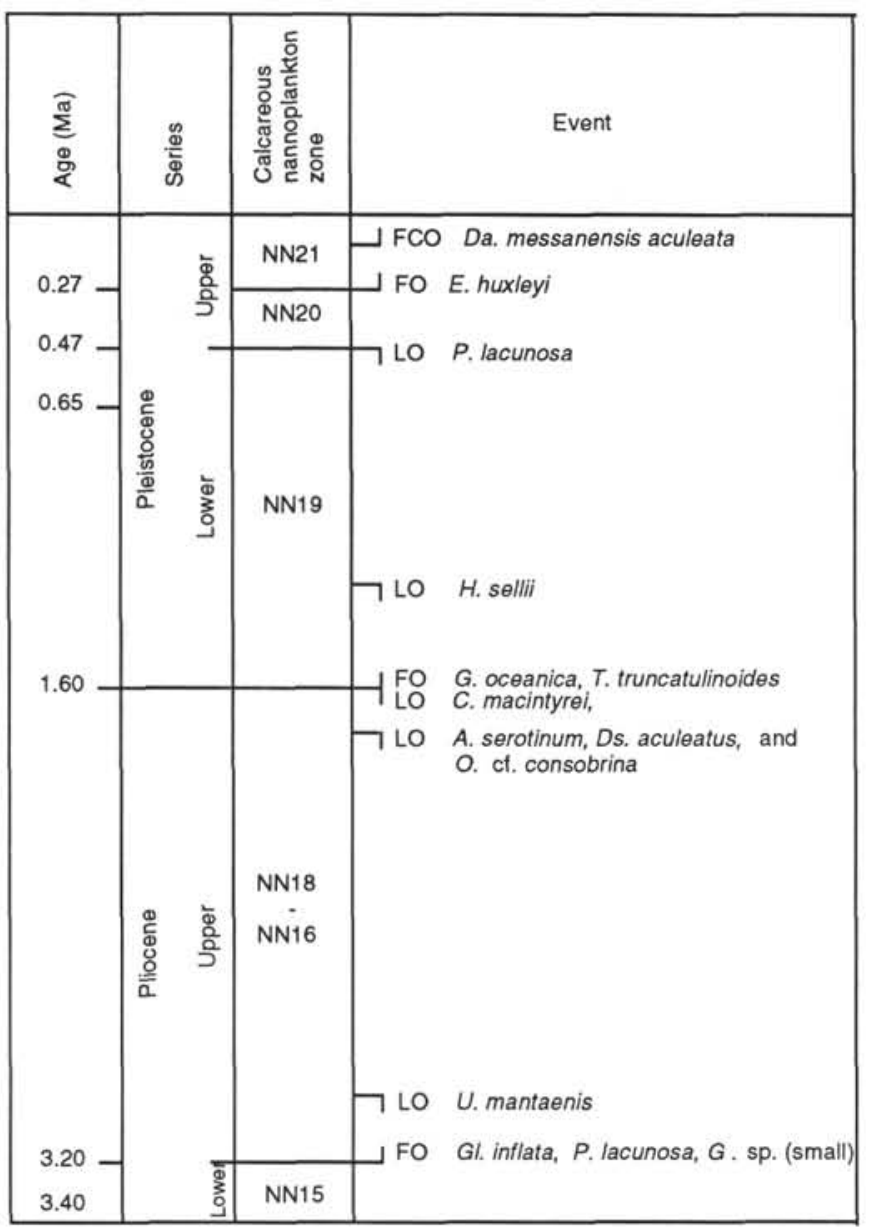

Figure 3. Biostratigraphic events and their age assignment for Leg 141. FO = first occurrence, $\mathrm{LO}=$ last occurrence, $\mathrm{FCO}=$ first consistent occurrence, $A .=$ Ammodochium, $C$. $=$ Cyclococcolithus, Da.$=$ Dictyocha, Ds. $=$ Distephanus, $E .=$ Emiliania,$G .=$ Gephyrocapsa,$G l .=$ Globoconella, $H .=$ Helicosphaera, $O .=$ Orthomorphina, $P .=$ Pseudoemiliania, $T .=$ Truncorotalia, $U .=$ Uvigerina.

(Locker, this volume). It is suggested that both subtropical planktonic foraminifers and transitional silicoflagellates were carried by warmwater masses from the Central Pacific to the south by strong El Niño events (Locker, this volume; Schönfeld et al., this volume). The warmwater masses transported during these events had a strong impact on the local climate in southern Chile (Schönfeld et al., this volume).

\section{CONCLUSIONS}

1. The combination of bioevents from various plankton groups (calcareous nannoplankton, planktonic foraminifers, silicoflagellates, and ebridians) provided a reasonable stratigraphic resolution of upper Pliocene and Quaternary sediments recovered at Sites 859 through 863 . The biozonations established represent high latitude subdivisions, because the study area was mainly influenced by subpolar water masses.

2. The Pliocene/Pleistocene boundary was determined by the FA of Gephyrocapsa oceanica, which corresponds to an age of $1.6 \mathrm{Ma}$. The LA events of the silicoflagellate Distephanus aculeatus and of the ebridian Ammodochium serotinum approach this boundary, thus indicating their stratigraphic value for higher latitudes.

3. Ecological preferences of the plankton species studied enable to describe paleoceanographic developments. The paleoceanography off southern Chile was generally characterized by the cold Peru current. But according to the occurrences of transitional silicoflagel- lates and subtropical planktonic foraminifers warmer surface water masses repeatedly expanded over the study area. The warm-adapted plankton was carried from the Central South Pacific to the southeast by strong El Niño events.

4. Stable oxygen isotope data indicate distinct paleotemperature fluctuations during the late Pleistocene. The record at Site 861 extends back to oxygen isotope event 10.2 , which is $0.34 \mathrm{Ma}$.

5. It is assumed that future plankton and stable isotope studies will lead to important insights into the variation of Quaternary paleoclimate and the interaction between ocean and continent of mid to high southern latitudes.

\section{REFERENCES}

Bé, A.W.H., and Tolderlund, D.S., 1971. Distribution and ecology of living planktonic foraminifera in surface waters of the Atlantic and Indian Oceans. In Funnel, B.M., and Riedel, W.R. (Eds.), The Micropaleontology of Oceans: Cambridge (Cambridge Univ. Press), 105-149.

Behrmann, J.H., Lewis, S.D., Musgrave, R.J., et al., 1992. Proc. ODP, Init. Repts., 141: College Station, TX (Ocean Drilling Program).

Berggren, W.A., Kent, D.V., Flynn, J.J., and Van Couvering, J., 1985. Neogene geochronology and chronostratigraphy. In Snelling, N.J. (Ed.), The Chronology of the Geological Record. Geol. Soc. London Mem.,10:211-250.

Blow, W.H., 1969. Late middle Eocene to Recent planktonic foraminiferal biostratigraphy. In Brönniman, P., and Renz, H.H. (Eds.), Proc. First Int. Conf. Planktonic Microfossils, Geneva, 1967: Leiden (E.J. Brill), 1:199-422.

Bolli, H.M., and Saunders, J.B., 1985. Oligocene to Holocene low latitude planktonic foraminifera. In Bolli, H.M., Saunders, J.B., and Perch-Nielsen, K. (Eds.), Plankton Stratigraphy: Cambridge (Cambridge Univ. Press), 155-262.

Boltovskoy, E., 1976. Distribution of Recent foraminifera of the South American region. In Hedley, R.H., and Adams, C.G. (Eds.), Foraminifera (Vol. 2): London (Academic Press), 171-237.

Boltovskoy, E., and Theyer, F., 1970. Foraminiferos recientes de Chile Central. Rev. Mus. Argent. Cienc. Nat. "Bernadino Rivadavia," Hidrobiol., 2:279379.

Brady, H.B., 1884. Report on the Foraminifera dredged by H.M.S. Challenger, during the years 1873-1876. Rep. Sci. Results Challenger Exped., Zool., 9:1-814.

d'Orbigny, A., 1839. Voyage dans l'Amerique Meridionale-foraminiferes. Ann. Sci. Nat., Ser. 5, 5:1-86.

Jenkins, D.G., and Gamson, P., 1993. The late Cenozoic Globorotalia truncatulinoides datum-plane in the Atlantic, Pacific and Indian oceans. In Hailwood, E.A., and Kidd, R.B. (Eds.), High Resolution Stratigraphy. Geol. Soc. Spec. Publ. London, 70:127-130.

Kennett, J.P., and Srinivasan, M.S., 1983. Neogene Planktonic Foraminifera: A Phylogenetic Atlas: Stroudsburg, PA (Hutchinson Ross).

Martini, E., 1971. Standard Tertiary and Quaternary calcareous nannoplankton zonation. In Farinacci, A. (Ed.), Proc. 2nd Int. Conf. Planktonic Microfossils Roma: Rome (Ed. Tecnosci.), 2:739-785.

Raffi, I., and Rio, D., 1979. Calcareous nannofossil biostratigraphy of DSDP Site 132-Leg 13 (Tyrrhenian Sea-Western Mediterranean). Riv. Ital. Paleontol. Stratigr, 85:127-172.

Resig, J.M., 1990. Benthic foraminiferal stratigraphy and paleoenvironments off Peru, Leg 112. In Suess, E., von Huene, R., et al., Proc, ODP, Sci. Results, 112: College Station, TX (Ocean Drilling Program), 263-296.

Srinivasan, M.S., and Kennett, J.P., 1981. A review of Neogene planktonic foraminiferal biostratigraphy: applications in the equatorial and South Pacific. In Warme, J.E., Douglas, R.G., and Winterer, E.L. (Eds.), The Deep Sea Drilling Project: A Decade of Progress. Spec. Publ.-Soc. Econ. Paleontol. Mineral., 32:395-432.

Thierstein, H.R., Geitzenauer, K., Molfino, B., and Shackleton, N.J., 1977. Global synchroneity of late Quaternary coccolith datum levels: validation by oxygen isotopes. Geology, 5:400-404.

"Abbreviations for names of organizations and publications in ODP reference lists follow the style given in Chemical Abstracts Service Source Index (published by American Chemical Society).

Date of initial receipt: 9 May 1994

Date of acceptance: 8 November 1994

Ms 141SR-036 